Kaswinami

Efektivitas Pendekatzn Bioantrepronourship terhadap

Hasil Belajar Kognitif Siswa melalui Lesson Study

Berorientasi Loorning Community

Rizal Kurniawan, Proptining Rahoyu

Pembelajaran hquiry dan Keternmpilan Peoses Sains

dalbm Implementrsi Kurikulum IPA di 5MP

siti Potonah, ovi Muitolio, Ennowoti

saptoningrus"

Leaming Outcame dalam Pembelajaran Fisika Berbasis

Virtual Lab

Sutamo, Agus Setiowo, Id Koniowoti, don Andi Suhandi

Analisis Butir Saal Ulangan Akhir Semeter Ganjil Mata

Pelajaran Biologi Kelas Xl ci SMA Kabupaten Kendal

siti Dewi Mownoh, Mei sulistyoningsih, Prosetiyo

Implementasi Praktikum Botani Tumbuhan Rendah

Berbasis SmaN Research Project untuk Meningkatkan Keterampilan Berpikir Kritis dan Siknp Ilmiah Mahasiswa

Pendidikan Biologi

Wachidatul Linda Yuhonna, Raraz Setyo Fetno

Inovasi Media dan Sumber Belajar

Model Pembelajaran Pendiclikan Anti Korupgi Eerbasis

Multimedia dengan Pendekatan Kontekstual sebagai 


\title{
Learning Outcome dalam Pembelajaran Fisika Berbasis Virtual Lab
}

\author{
Sutarno ${ }^{1,2, *}$, Agus Setiawan ${ }^{1}$, Ida Kaniawati ${ }^{1}$, dan Andi Suhandi ${ }^{1}$ \\ ${ }^{1}$ Program Studi Pendidikan IPA, Sekolah Pascasarjana, Universitas Pendidikan Indonesia, Jl. Dr. \\ Setiabudhi No. 229, Bandung \\ ${ }^{2}$ Program Studi Pendidikan Fisika, Fakultas Keguruan dan IImu Pendidikan, Universitas \\ Bengkulu, JI. W.R Supratman, Kandang Limun, Bengkulu \\ *Email: m.sutarno@unib.ac.id
}

\begin{abstract}
Abstrak
Penelitian ini bertujuan mengekplorasi bentuk learning outcome, model pembelajaran, dan metode utama yang digunakan dalam pembelajaran fisika berbasis virtual lab. Metode yang digunakan dalam penelitian ini adalah studi literatur, berupa analisis dan sintesis terhadap 26 artikel ilmiah dari berbagai jurnal internasional ternama. Artikel ilmiah yang dipilih dibatasi pada tahun publikasi 2011 sampai dengan 2016. Berdasarkan hasil analisis diperoleh gambaran: (1) model pembelajaran yang digunakan adalah learning cycle 5E, e-learning, blended learning, dan dual-situated learning; (2) metode pembelajaran utama yang digunakan adalah eksperimen, demonstrasi, dan inkuiri; (3) bentuk pengetahuan yang menjadi tujuan pembelajaran adalah pengetahun konseptual berupa penguasaan/pemahaman konsep; pengetahuan prosedural; perubahan konsepsi; dan miskonsepsi dan cognitive load; (4) aspek keterampilan yang dieksplorasi adalah keterampilan inkuiri dan keterampilan manipulatif dalam aktivitas praktik; (5) aspek afeksi yang menjadi bahan kajian adalah sikap terhadap fisika; sikap terhadap praktikum virtual; sikap terhadap virtual lab; tingkat keyakinan siswa dalam menerapkan konsep-konsep fisika; dan epistemological belief; (6) pada semua artikel yang dianalisis, ditemukan bahwa penggunaan virtual lab dapat meningkatkan penguasaan/pemahaman konsep fisika siswa. Tidak ditemukan pengembangan atau penggunaan virtual lab yang secara sengaja dirancang untuk melatihkan keterampilan berpikir tingkat tinggi dan keterampilan penting lainnya. Perlu dilakukan pengembangan dan pemanfaatan virtual lab yang dapat membekalkan keterampilan abad 21 kepada siswa.
\end{abstract}

Kata Kunci: learning outcome, virtual lab, pembelajaran fisika, keterampilan abad 21

\section{Pendahuluan}

Saat ini paradigma pembelajaran telah bergeser dari pembelajaran konvensional menuju pembelajaran berbasis teknologi, khususnya teknologi ICT (information and communication technology). Pembelajaran berbasis teknologi memberikan ruang kepada pebelajar untuk memperoleh pengetahuan melalui berbagai sumber. Kenyataan ini menempatkan guru bukanlah sebagai satu-satunya sumber ilmu, melainkan pengetahuan dapat diperoleh dari manapun dengan kemudahan teknologi ICT. Oleh karena itu, guru harus dapat menyesuaikan diri dan mengadaptasi teknologi ICT dalam proses pembelajaran di kelas.

Pembelajaran fisika pada hakikatnya menekankan pada pembelajaran aktif yang direpresentasikan melalui aktivitas fisik maupun mental, tidak hanya mencakup aktivitas hands-on melainkan juga mindson. Proses pembelajaran fisika harus diarahkan pada aktivitas inkuiri untuk memperoleh pengalaman dan pemahaman yang lebih mendalam tentang alam sekitar. Pembelajaran fisika bertujuan untuk menumbuhkan scientific skills berupa 
science process skill, thinking skill, dan science attitude. Pada konteks ini, pembelajaran fisika potensial dalam mendorong konsep pembelajaran abad 21 yang menekankan pada penguasaan keterampilan-keterampilan penting abad 21. Keterampilan abad 21 dikelompokkan ke dalam empat bagian, yaitu ways of thinking, ways of working, tools for working, dan living in the world (Binkley et al, 2012). Ways of thinking terdiri atas kreativitas dan inovasi; keterampilan berpikir kritis, pemecahan masalah, pengambilan keputusan; dan metakognisi. Ways of working terdiri atas keterampilan berkomunikasi dan kolaborasi. Tools of working terdiri atas literasi informasi dan literasi ICT. Sedangkan living in the world terdiri atas keterampilan kewarganegaraan (lokal dan global), hidup dan berkarir, serta keperdulian personal dan sosial.

Konsep pembelajaran abad 21 harus diterapkan pada pembelajaran fisika baik di ruang kelas maupun melalui aktivitas laboratorium. Kedua bentuk aktivitas tersebut tidak dapat dipisahkan satu sama lain mengingat fisika secara hakikat dibentuk dari aspek produk, proses, sikap, dan aplikasi fisika sebagai satu kesatuan yang tak terpisahkan. Pada pembelajaran fisika, keempat aspek tersebut harus dijadikan tujuan utama pembelajaran yang akan dicapai secara bersamaan.

Salah satu aktivitas penting di lingkungan laboratorium adalah kegiatan praktikum. Beberapa penelitian berhasil mengekplorasi manfaat praktikum, diantaranya yaitu praktikum dapat dijadikan sebagai wahana untuk mengkonstruksi, merekonstruksi, memverifikasi, dan memperkuat pengetahuan ilmiah (Tobin, 1990). Aktivitas praktikum dapat melatihkan keterampilan dasar bereksperimen dan metode ilmiah (Hofstein \& Lunneta, 2004). Kegiatan praktikum dapat menstimulai perkembangan keterampilan berpikir tingkat rendah menuju keterampilan berpikir tingkat tinggi (Deacon \& Hajek, 2010). Aktivitas praktikum potensial melatih keterampilan komunikasi dan kolaborasi ilmiah. Selain itu, aktivitas praktikum berbasis teknologi ICT berpotensi melatihkan literasi informasi dan ICT.

Mengingat banyak manfaat yang dapat diperoleh dari aktivitas praktikum, sekolah dan perguruan tinggi seyogyanya dilengkapi dengan sarana dan prasarana laboratorium sesuai standar kebutuhan. Peserta didik perlu dilibatkan dalam berbagai pengalaman agar mereka mampu mengkonstruksi dan memperoleh beragam pengetahuan, keterampilan, dan sikap ilmiah. Namun demikian, secara umum praktikum yang dilakukan belum mampu memberikan manfaat sesuai harapan akibat berbagai keterbatasan dan hambatan. Hambatan utama yang umumnya ditemukan adalah keterbatasan peralatan praktikum, kesulitan guru dalam merancang dan melaksanakan praktikum (Putri \& Sutarno, 2014; Malik, et al., 2015) dan aktivitas praktikum yang masih lakukan secara konvensional (Malik \& Setiawan, 2016). Pada praktikum konvensional, guru mengalami kesulitan dalam mengontrol proporsi aktivitas hands-on dan minds-on, akibatnya kegiatan praktikum hanya dominan pada aktivitas motorik, sedangkan aktivitas kognitif terabaikan. Praktikum konvensional menjadi kurang mampu melatihkan keterampilan berpikir tingkat tinggi (Hodson, 1990). 
Banyaknya tantangan dan hambatan dalam kegiatan praktikum mendorong penggunaan strategi baru dalam praktikum. Sutrisno (2012) menyarankan penggunaan virtual lab sebagai alternatif bagi kegiatan praktikum, terutama untuk konsep-konsep abstrak yang tidak mungkin dilakukan di laboratorium akibat ketiadaan peralatan. Praktikum virtual menggunakan teknologi virtual lab dapat digunakan untuk memaksimalkan aktivitas minds-on siswa (Taslidere, 2015).

Banyak hasil penelitian yang membuktikan manfaat penggunaan virtual lab dalam pembelajaran fisika, diantaranya ditemukan bahwa pemanfaatan virtual lab dapat meningkatkan pemahaman konsep fisika (Darrah, et al., 2014; Bajpai \& Kumar, 2015; Srisawasdi \& Krootkeaw, 2014). Efektivitas penggunaan virtual lab dalam meningkatkan pemahaman konsep siswa sama baiknya dengan aktivitas hands-on lab (Finstein, et al., 2013; Chao, et al., 2015). Hasil belajar fisika siswa yang menggunakan virtual lab lebih baik dibandingkan dengan yang mengikuti aktivitas hands-on di laboratorium (Pyatt \& Sims, 2012; Civelek, et al., 2014).

Penelitian-penelitian tersebut mengungkapkan berbagai keuntungan pemanfaatan virtual lab dalam pembelajaran fisika, namun demikian belum memberikan informasi yang cukup terkait seberapa jauh pengembangan dan penggunaan virtual lab telah diarahkan untuk membekalkan keterampilan abad 21. Penelitian ini dilakukan untuk mengeksplorasi aspek dan hasil pembelajaran fisika berbasis virtual lab yang dilakukan di berbagai negara melalui analisis artikel jurnal internasional. Informasi yang didapatkan dapat dijadikan sebagai acuan dalam pengembangan dan pemanfaatan teknologi virtual lab yang secara sengaja diarahkan untuk melatih keterampilan abad 21 kepada siswa.

\section{Metode Penelitian}

Metode yang digunakan dalam penelitian ini adalah studi literatur, berupa analisis dan sintesis terhadap artikel ilmiah dari berbagai jurnal internasional ternama. Artikel yang dianalisis memuat hasil studi tentang pengembangan dan penggunaan virtual lab dalam pembelajaran fisika. Artikel ilmiah yang digunakan diperoleh melalui google schoolar, web of science, ebscohost EJS, academic search complete, springerlink, master file premier, ERIC, psychology and behavioral science collection, dan beberapa sumber lainnya. Proses pencarian dibatasi pada artikel jurnal yang dipublikasi pada rentang tahun 2011 sampai dengan 2016. Berdasarkan proses pencarian dari sumber penyedia database tersebut didapatkan 26 artikel jurnal yang akan dianalisis.

Artikel jurnal yang didapatkan selanjutnya dianalisis dan disintesis untuk memperoleh informasi terkait aspek learning outcome (hasil belajar), model pembelajaran, dan metode utama yang diguanakan dalam pembelajaran fisika berbantuan virtual lab (simulasi komputer interaktif). Aspek learning outcome yang diidentifikasi terdiri atas ranah pengetahuan (knowledge), keterampilan (skills), dan afeksi (affection). Analisis selanjutnya difokuskan pada identifikasi perbandingan hasil belajar fisika antara siswa yang mengikuti pembelajaran menggunakan virtual lab dengan siswa yang mengikuti pembelajaran secara konvensional menggunakan hands-on lab. Selain itu, juga dilakukan identifikasi terkait topik-topik fisika yang dipelajari melalui virtual lab. Data hasil analisis selanjutnya 
diorganisasi, dikoding, dikategorisasi, dan diinterpretasi untuk memperoleh informasi sesuai tujuan penelitian.

\section{Hasil Penelitian dan Pembahasan}

Proses analisis dilakukan untuk menggali informasi terkait (1) model dan metode utama yang digunakan dalam pembelajaran fisika berbantuan virtual lab; (2) bentuk learning outcome berupa pengetahuan, keterampilan, dan afeksi; (3) hasil belajar siswa setelah mengikuti pembelajaran atau praktikum fisika menggunakan virtual lab; dan (4) konsepkonsep fisika yang dipelajari melalui virtual lab. Hasil analisis terhadap 26 artikel jurnal internasional ditunjukkan pada Tabel 1 , Tabel 2, dan Tabel 3.

Model dan metode yang digunakan dalam pembelajaran fisika berbasis virtual lab ditunjukkan pada Tabel 1. Terlihat hanya terdapat 4 model pembelajaran aktif yang digunakan pada pembelajaran fisika berbasis virtual lab, yaitu model pembelajaran learning cycle $5 E$, model

Tabel 1. Model dan Metode Pembelajaran yang Digunakan dalam Pembelajaran Fisika Berbasis

\begin{tabular}{clc}
\multicolumn{1}{c}{ Virtual Lab } & \multicolumn{1}{c}{ Nama Model/Metode Pembelajaran } & Jumlah \\
\hline Aspek & \multicolumn{1}{c}{ Model Pembelajaran Siklus Belajar 5 E } & 2 \\
& Model Pembelajaran Berbasis Website (E-Learning) & 4 \\
& Model Dual-Situated Learning & 1 \\
& Model Blended Learning & 1 \\
Metode Pembelajaran & Metode Eksperimen & 15 \\
& Metode Demonstrasi & 7 \\
& Metode Inkuiri & 4 \\
\hline
\end{tabular}

Bentuk learning outcome dalam pembelajaran fisika berbasis virtual lab ditunjukkan pada Tabel 2. Terlihat bahwa hampir seluruh pembelajaran yang dilakukan (92,3\%) ditujukan untuk meningkatkan aspek penguasaan/ pemahaman konsep. Sedangkan aspek pengetahuan lainnya yang menjadi tujuan pembelajaran adalah meningkatkan pengetahuan prosedural $(3,8 \%)$, perubahan konsepsi $(3,8 \%)$, mengurangi miskonsepsi $(3,8 \%)$, dan menurunkan pembelajaran berbasis website (elearning), model dual-situated learning, dan model blended learning. Model pembelajaran tersebut ditemukan pada 8 artikel jurnal yang dianalisis. Sedangkan 18 artikel lainnya tidak menyatakan secara jelas model pembelajaran yang digunakan. Sementara itu, metode pembelajaran uyama yang digunakan dalam pembelajaran fisika berbasis virtual lab adalah metode eksperimen (57,7\%), metode demonstrasi $(26,9 \%)$, dan metode inkuiri $(15,4 \%)$. Metode pembelajaran yang digunakan pada sebagian besar artikel tidak dinyatakan secara jelas, tetapi dapat diinterpretasi berdasarkan aktivitas pembelajaran yang dijelaskan pada bagian metodologi penelitian, serta hasil penelitian dan pembahasan. Metode pembelajaran yang dinyatakan pada penelitian ini hanya metode pembelajaran yang dominan digunakan pada masingmasing pembelajaran. beban kognitif (3,8\%). Aspek keterampilan yang teridentifikasi sebagai tujuan pembelajaran adalah keterampilan inkuiri ilmiah (3,8\%), dan keterampilan manipulatif dalam aktivitas praktik $(3,8 \%)$. Sedangkan aspek sikap yang dieksplorasi melalui pembelajaran fisika menggunakan virtual lab adalah sikap terhadap fisika $(7,7 \%)$, sikap terhadap praktikum virtual $(11,5 \%)$, sikap terhadap teknologi virtual lab yang dikembangkan/digunakan $(11,5 \%)$, tingkat kepercayaan siswa dalam 
menerapkan konsep-konsep fisika dalam memecahkan persoalan fisika $(7,7 \%)$, dan epistemological belief (3,8\%). Berdasarkan data hasil analisis terlihat bahwa pembelajaran fisika berbasis virtual lab belum ditujukan untuk melatih dan meningkatkan keterampilan abad 21 berupa keterampilan berpikir tingkat tinggi, keterampilan komunikasi dan kolaborasi, literasi informasi dan literasi $\mathrm{ICT}$, serta keterampilan living in the world.

Tabel 2. Bentuk Learning Outcome dalam Pembelajaran Fisika Berbasis Virtual Lab

\begin{tabular}{llc}
\hline \multicolumn{1}{c}{ Aspek } & \multicolumn{1}{c}{ Hasil Identifikasi } & Jumlah \\
\hline Pengetahuan (Knowledge) & Pengetahuan konseptual berupa penguasaan/pemahaman & 24 \\
& konsep & 1 \\
& Pengetahuan prosedural & 1 \\
& Perubahan konseptual & 1 \\
& Miskonsepsi & 1 \\
& Cognitive load & 1 \\
Keterampilan (Skills) & Keterampilan inkuiri ilmiah & 1 \\
& Keterampilan manipulatif dalam aktivitas praktik & 2 \\
Sikap (Affection) & Sikap terhadap fisika & 3 \\
& Sikap terhadap praktikum virtual & 3 \\
& Sikap terhadap virtual lab yang dikembangkan & 2 \\
& Tingkat kepercayaan diri siswa dalam menerapkan konsep- & \\
& konsep fisika untuk memecahkan persoalan fisika & 1
\end{tabular}

Tabel 3 memperlihatkan hasil pembelajaran fisika berbasis virtual lab, teramati bahwa pemanfaatan virtual lab sangat efektif dalam meningkatkan penguasaan/pemahaman konsep siswa. Hal ini dibuktikan dengan sebanyak $96,2 \%$ dari jumlah pembelajaran yang diidentifikasi menghasilkan peningkatan penguasaan/ pemahaman konsep siswa setelah mengikuti pembelajaran berbasis virtual lab. Penggunaan virtual lab juga dapat meminimalisir miskonsepsi dan menurunkan beban kognitif siswa. Pada aspek keterampilan, terdapat peningkatan keterampilan inkuiri ilmiah dan keterampilan manipulatif siswa pada aktivitas praktikum virtual. Selain itu, teridentifikasi bahwa peningkatan hasil belajar siswa yang mengikuti praktikum virtual secara signifikan lebih besar dibandingkan dengan yang mengikuti praktikum hands-on di laboratorium.

Berdasarkan hasil analisis juga teridentifikasi bahwa terdapat 30 konsep fisika yang terdapat pada virtual lab yang digunakan. Sebanyak 28 dari 30 konsep yang ditemukan diantaranya merupakan konsep fisika dasar, dan 2 konsep lainnya merupakan konsep fisika modern. Konsep fisika dasar yang dijadikan topik praktikum pada virtual lab diantaranya adalah konsep Hukum II Newton, gerak relatif, massa dan berat, gerak harmonis sederhana, optik geometris, sifat gas, gaya gravitasi, tumbukan elastik, Hukum Hook, tekanan hidrostatis, hukum kekekalan energi, gaya sentripetal, dan lain-lain. Sedangkan konsep fisika modern yang teridentifikasi adalah konsep efek fotolistrik dan relativitas khusus. Data tersebut menunjukkan bahwa konsep-konsep yang diekplorasi melalui virtual lab umumnya bukanlah konsep yang bersifat mikroskopis dengan abstraksi tinggi. Beberapa peneliti menyatakan bahwa virtual lab tepat digunakan untuk mengekplorasi konsepkonsep abstrak, kompleks, dan bersifat mikroskopis yang tidak memungkinkan dapat dilakukan/dihadirkan di laboratorium (Bajpai, 2013; Taslidere, 2015; Bajpai \& Kumar, 2015). Penggunaan virtual lab diantaranya dimaksudkan sebagai media untuk memvisualisasi konsep-konsep atau proses mikroskopis 
yang tidak dapat diamati menggunakan

tersedia.

indera manusia dan peralatan yang

Tabel 3. Hasil Belajar Siswa dalam Pembelajaran Fisika Berbasis Virtual Lab

\begin{tabular}{|c|c|c|}
\hline Desain Pembelajaran & Hasil Belajar & Jumlah \\
\hline $\begin{array}{l}\text { Menguji Kemampuan virtual } \\
\text { lab dalam meningkatkan }\end{array}$ & $\begin{array}{l}\text { Penguasaan/pemahaman konsep siswa mengalami peningkatan } \\
\text { setelah mengikuti pembelajaran fisika menggunakan virtual lab }\end{array}$ & 25 \\
\hline $\begin{array}{l}\text { penguasaan/pemahaman } \\
\text { konsep fisika }\end{array}$ & $\begin{array}{l}\text { Beban kognitif (cognitive load) siswa mengalami penurunan } \\
\text { seteleh mengikuti pembelajaran fisika menggunakan virtual lab }\end{array}$ & 1 \\
\hline $\begin{array}{l}\text { Menguji Kemampuan virtual } \\
\text { lab dalam meningkatkan }\end{array}$ & $\begin{array}{l}\text { keterampilan inkuiri siswa mengalami peningkatan setelah } \\
\text { mengikuti pembelajaran fisika menggunakan virtual lab }\end{array}$ & 1 \\
\hline keterampilan siswa & $\begin{array}{l}\text { Keterampilan manipulatif siswa dalam aktivitas praktik } \\
\text { mengalami peningkatan dalam pembelajaran fisika } \\
\text { menggunakan virtual lab }\end{array}$ & 1 \\
\hline $\begin{array}{l}\text { Membandingkan } \\
\text { peningkatan hasil belajar } \\
\text { antara siswa yang mengikuti }\end{array}$ & $\begin{array}{l}\text { Peningkatan hasil belajar siswa yang mengikuti praktikum } \\
\text { secara virtual lebih tinggi dibandingkan siswa yang melakukan } \\
\text { praktikum hands-on lab }\end{array}$ & 5 \\
\hline $\begin{array}{l}\text { praktikum virtual dengan } \\
\text { siswa yang melakukan } \\
\text { praktikum hands-on lab }\end{array}$ & $\begin{array}{l}\text { Peningkatan hasil belajar siswa yang mengikuti praktikum virtual } \\
\text { tidak berbeda signifikan dengan siswa yang mengikuti praktikum } \\
\text { hands-on di laboratorium }\end{array}$ & 5 \\
\hline \multirow{2}{*}{$\begin{array}{l}\text { Membandingkan hasil belajar } \\
\text { antara siswa yang mengikuti } \\
\text { praktikum campuran (virtual } \\
\text { lab + hands-on lab) dengan } \\
\text { yang mengikuti praktikum } \\
\text { virtual atau hands-on lab saja }\end{array}$} & $\begin{array}{l}\text { Peningkatan hasil belajar siswa yang mengikuti praktikum } \\
\text { campuran (virtual lab + hands-on lab) secara signifikan lebih } \\
\text { besar dibandingkan siswa yang mengikuti praktikum virtual atau } \\
\text { hand-on lab saja }\end{array}$ & 2 \\
\hline & $\begin{array}{l}\text { Peningkatan hasil belajar siswa yang mengikuti praktikum } \\
\text { campuran (virtual lab + hands-on lab) tidak berbeda signifikan } \\
\text { dengan siswa yang mengikuti praktikum virtual atan hands-on } \\
\text { lab saja }\end{array}$ & 1 \\
\hline
\end{tabular}

Secara keseluruhan hasil analisis menunjukkan bahwa penggunaan virtual lab dalam pembelajaran fisika masih lebih diorientasikan untuk meningkatkan penguasaan atau pemahaman siswa pada konsep-konsep fisika yang dipelajari. Lembar kerja siswa atau permasalahan yang digunakan dalam praktikum virtual hanya difokuskan pada pencapaian aspek pengetahuan (knowledge), sedangkan aspek proses dan keterampilan berpikir tingkat tinggi terabaikan. Tidak ditemukan satupun pembelajaran fisika berbasis virtual lab yang diorientasikan untuk mengembangkan kreativitas dan inovasi; keterampilan berpikir kritis, keterampilan problem solving, keterampilan pengambilan keputusan, metakognisi, keterampilan berkomunikasi dan kolaborasi, literasi informasi dan literasi $\mathrm{ICT}$, dan keterampilan living in the world sebagaimana ditekankan pada konsep pembelajaran abad 21.

Hasil penelitian mengindikasikan pentingnya pengembangan atau pemanfaatan teknologi virtual lab yang secara sengaja ditujukan untuk melatih, membekalkan, dan mengembangkan keterampilan abad 21 siswa. Terdapat dua alternatif yang dapat ditempuh, yaitu: (1) virtual lab yang digunakan sengaja dikembangkan dengan mengadaptasi langkah-langkap pembelajaran inovatif seperti inkuiri, problem solving, learning cycle, atau model-model lainnya ke dalam interface virtual lab. Virtual lab seperti ini dapat menuntuk user (siswa) dalam memecahkan masalah menggunakan tahap-tahap yang sudah ada (include) di dalam virtual lab. Salah satu contoh pengembangan virtual lab yang mengadopsi cara ini adalah online virtual 
lab yang dikembangkan oleh De Jong, et al (2014). Online virtual lab tersebut mengadaptasi sintak model inkuiri terbimbing yang terdiri atas fase orientasi, konseptualisasi, investigasi, interpretasi, kesimpulan, dan diskusi. (2) menggunakan virtual lab atau simulasi komputer yang sudah tersedia (misalnya simulasi PhET). Pembekalan keterampilan abad 21 melalui cara kedua ini dapat dilakukan melalui pengembangan lembar kerja praktikum (LKP) yang akan menuntun siswa pada prosedur praktikum virtual yang akan dilakukan. LKP yang dikembangkan harus mengadaptasi ciri keterampilan abad 21 yang akan dilatihkan, misalnya memuat indikator-indikator keterampilan berpikir kritis, keterampilan berpikir kreatif, dan sebagainya.

\section{Kesimpulan}

Berdasarkan hasil penelitian dapat disimpulkan: (1) model pembelajaran yang digunakan dalam pembelajaran fisika berbasis virtual lab adalah learning cycle $5 \mathrm{E}$, e-learning, blended learning, dan dualsituated learning; (2) metode pembelajaran utama yang digunakan adalah eksperimen, demonstrasi, dan inkuiri; (3) learning outcome yang menjadi tujuan utama pembelajaran didominasi oleh aspek pengetahun konseptual berupa penguasaan/pemahaman konsep; (4) pemahaman konsep siswa mengalami peningkatan setelah mengikuti pembelajaran fisika berbasis virtual lab. Tidak ditemukan pengembangan atau penggunaan virtual lab yang secara sengaja dirancang untuk melatihkan keterampilan berpikir tingkat tinggi atau keterampilan penting lainnya. Perlu dilakukan pengembangan dan pemanfaatan virtual lab yang dapat membekalkan keterampilan abad 21 kepada siswa.

\section{Ucapan Terimakasih}

Penelitian ini didukung oleh

Kementrian Riset, Teknologi, dan Pendidikan Tinggi (Ristekdikti) melalui Beasiswa Program Pascasarjana Dalam Negeri di Universitas Pendidikan Indonesia. Penulis mengucapkan terimakasih atas seluruh fasilitas yang diberikan.

\section{Daftar Pustaka}

Bajpai, M. (2013). Developing concepts in physics through virtual lab experiment: an effectiveness study. International Journal of Educational Technology, 3(1) : 43-50

Bajpai, M. \& Kumar, A. (2015). Effect of virtual laboratory on student's conceptual achievement in physics. International Journal of Current Research, 7(02).

Binkley, M., Erstad, O., Herman, J., Raizen, S., Ripley, M., Ricci, M. M., \& Rumble, M. (2012). Defining twenty-first century skills (Griffin, et al, Eds : Assessment and teaching of $21^{\text {st }}$ century skills). New York.

Civelek, T., Ucar, E., Ustunel, H. \& Aydin, M.K. (2014). Effects of haptic augmented simulation on K-12 students' achievement and their attitudes towards physics. Eurasia Journal of Mathematics, Science \& Technology Education, 10(6) : 565574.

Chao, J. dkk. (2015). Sensor-augmented virtual labs: using physical interactions with science simulations to promote understanding of gas behavior. I Sci Educ Technol.

Darrah, M., Humbert, R., Finstein, J., Simon, M. \& Hopkins, J. (2014). Are virtual labs as effective as hands-on labs for undergraduate physics? a comparative study at two major 
universities. Journal of Science Education Technology, 23 : 803-814.

Deacon, C \& Hajek, K. (2010). Student perceptions of the value of physics laboratories. International Journal of Science Education, 1-35.

De Jong, T., Sotiriou, S. \& Gillet, D. (2014). Innovation in STEM education : the go-lab federation of online labs. Smart Learning Envoronments, 1(3).

Finstein, J., Darrah, M. \& Humbert, R. (2013). Do students in general high school physics classes learn as much from virtual labs as form hands-on labs?. National Teacher Education Journal, 6(3) : 61-70.

Hodson, D. (1990). A critical look at practical working school science. School Science Review, 71(1) : 33-40.

Hofstein, A \& Lunneta, V.N. (2004). The labority in science education: foundations for the twenty first century. Science Education, 88: 28-54.

Malik, A., Handayani, W \& Nuraini, R. (2015). Model Praktikum Problem Solving Laboratory untuk Meningkatkan Keterampilan Proses Sains Mahasiswa. Prosiding Simposium Nasional Inovasi dan Pembelajaran Sains. Bandung, Indonesia
Pyatt, K. \& Sims, R. (2011). Virtual and physical experimentation in inquirybased science labs: attitudes, performance and access. I Sci Educ Technol, 21 : 133-147.

Putri, D. H \& Sutarno, M. (2014). Profil peralatan dan keterlaksanaan praktikum fisika SMA di wilayah miskin Propinsi Bengkulu. Jurnal Exacta, 12 (1).

Srisawasdi, N. \& Kroothkeaw, S. (2014). Supporting students' conceptual development of light refraction by simulation-based open inquiry with dual-situated learning model. J. Comput. Educ, 1(1) : 49-79.

Sutrisno. (2012). Kreatif Mengembangkan Aktivitas Pembelajaran Berbasis TIK. Jakarta: Referensi.

Taslidere, E. (2015). A study investigating the effect of treatment developed by integrating the $5 \mathrm{E}$ and simulation on pre-service science teacher's achievement in photoelectric effect. Eurasia Journal of Mathematics, Science and Technology Education, 11(4) : 777-792.

Tobin, K. (1990). Research on science laboratory activities: In pursuit of better questions and answers to improve learning. School Science and Mathematics, 90(5) : 403-418. 